\title{
Bacillus xiaoxiensis sp. nov., a slightly halophilic bacterium isolated from non-saline forest soil
}

\author{
Correspondence \\ Yi-Guang Chen \\ mchenjsu@yahoo.com.cn \\ Wen-Jun Li \\ wjli@ynu.edu.cn
}

\author{
Yi-Guang Chen, ${ }^{1}$ Yu-Oin Zhang, ${ }^{2}$ Oi-Hui Chen, ${ }^{1}$ Hans-Peter Klenk, ${ }^{3}$ \\ Jian-Wu He, ${ }^{1}$ Shu-Kun Tang, ${ }^{4}$ Xiao-Long Cui ${ }^{4}$ and Wen-Jun Li, ${ }^{4,5}$
}

\footnotetext{
${ }^{1}$ Key Laboratory of Ecotourism's Application Technology of Hunan Province, College of Biology and Environmental Sciences, Jishou University, Jishou 416000, PR China

${ }^{2}$ Institute of Medicinal Biotechnology, Chinese Academy of Medical Sciences and Peking Union Medical College, Beijing 100050, PR China

${ }^{3}$ Deutsche Sammlung von Mikroorganismen und Zellkulturen, D-38124 Braunschweig, Germany

${ }^{4}$ Key Laboratory of Microbial Diversity in Southwest China, Ministry of Education and Laboratory for Conservation and Utilization of Bio-Resources, Yunnan Institute of Microbiology, Yunnan University, Kunming 650091, PR China

${ }^{5}$ Guangdong Key Laboratory of Marine Materia Medica, South China Sea Institute of Oceanology, Chinese Academy of Sciences, Guangzhou 510301, PR China
}

\begin{abstract}
A novel Gram-stain-positive, slightly halophilic, catalase-positive, oxidase-negative, endosporeforming, motile, facultatively anaerobic, rod-shaped bacterium, designated strain JSM 081004 ${ }^{\top}$, was isolated from non-saline forest soil in Xiaoxi National Natural Reserve, China. Growth occurred with $0.5-20 \%(\mathrm{w} / \mathrm{v}) \mathrm{NaCl}$ (optimum 2-4\%), at $\mathrm{pH} 6.0-10.5$ (optimum $\mathrm{pH} 8.0$ ) and at $5-40{ }^{\circ} \mathrm{C}$ (optimum $25-30{ }^{\circ} \mathrm{C}$ ). meso-Diaminopimelic acid was present in the cell-wall peptidoglycan. The major cellular fatty acids were iso- $\mathrm{C}_{15: 0}$ and anteiso- $\mathrm{C}_{15: 0}$. Strain JSM $081004^{\top}$ contained MK-7 as the predominant respiratory quinone, and diphosphatidylglycerol, phosphatidylethanolamine and phosphatidylglycerol as the major polar lipids. The genomic DNA $\mathrm{G}+\mathrm{C}$ content of strain JSM $081004^{\top}$ was $40.1 \mathrm{~mol} \%$. Phylogenetic analysis based on $16 \mathrm{~S}$ rRNA gene sequence comparisons revealed that strain JSM $081004^{\top}$ should be assigned to the genus Bacillus and was most closely related to the type strains of Bacillus lehensis (sequence similarity 97.8\%), Bacillus oshimensis (97.8\%) and Bacillus patagoniensis (97.3\%). Phylogenetic analysis, DNA-DNA relatedness values, phenotypic characteristics and chemotaxonomic data all support the proposal of strain JSM $081004^{\top}$ as a representative of a novel species of the genus Bacillus, for which the name Bacillus xiaoxiensis sp. nov. is proposed; the type strain is JSM $081004^{\top}\left(=\right.$ CCTCC AA $208057^{\top}=$ DSM $\left.21943^{\top}\right)$.
\end{abstract}

Halophilic, halotolerant, alkaliphilic and/or alkalitolerant bacilli species are not only widely distributed throughout various types of saline environments (Ash et al., 1991; Nielsen et al., 1994; Ventosa et al., 1998; Arahal \& Ventosa, 2002; Romano et al., 2005; Lim et al., 2006a, b; Yumoto, 2007; Chen et al., 2009a, b), but have also been isolated from non-saline environments (Nielsen et al., 1995; Echigo et al., 2005, 2007; Usami et al., 2007). These bacteria have attracted increasing interest, attributable to their ability to grow under extreme conditions as well as to the potential use of their enzymes in biotechnological applications (Horikoshi, 1999; Margesin \& Schinner, 2001; Nogi et al.,

The GenBank/EMBL/DDBJ accession number for the $16 \mathrm{~S}$ rRNA gene sequence of strain JSM $081004^{\top}$ is HM054474.

A supplementary figure is available with the online version of this paper.
2005; Krulwich et al., 2007). During an investigation of the diversity of halophilic and halotolerant bacteria in Xiaoxi National Natural Reserve $\left(28^{\circ} 42^{\prime} 15^{\prime \prime}\right.$ to $28^{\circ} 53^{\prime} 15^{\prime \prime} \mathrm{N} 110^{\circ}$ $6^{\prime} 50^{\prime \prime}$ to $110^{\circ} 21^{\prime} 35^{\prime \prime} \mathrm{E}$ ), Hunan Province, China (Chen et al., 2010), a slightly halophilic, endospore-forming, Gram-stain-positive bacterium, designated strain JSM $081004^{\mathrm{T}}$, was isolated from a non-saline forest soil sample. Based on the results of a polyphasic taxonomic study, this strain is considered to represent a novel species of the genus Bacillus.

Strain JSM $081004^{\mathrm{T}}$ was isolated from a non-saline forest soil sample by using the dilution plating technique on marine agar 2216 (MA; Difco) supplemented with $10 \%$ $(\mathrm{w} / \mathrm{v}) \mathrm{NaCl}$ and cultivated at $28{ }^{\circ} \mathrm{C}$ for 2 weeks. After primary isolation and purification, the isolate was maintained as serial transfers on MA slants, as lyophilized 
cultures at $4{ }^{\circ} \mathrm{C}$ and also deep-frozen at $-80{ }^{\circ} \mathrm{C}$ in $20 \%$ (v/v) glycerol. Three type strains, Bacillus lehensis DSM $19099^{\mathrm{T}}$, Bacillus oshimensis DSM $18940^{\mathrm{T}}$ and Bacillus patagoniensis DSM $16117^{\mathrm{T}}$, obtained from the Deutsche Sammlung von Mikroorganismen und Zellkulturen (DSMZ, Braunschweig, Germany), were used as reference strains for comparison. Unless otherwise indicated, morphological, physiological, molecular and chemotaxonomic studies were performed with cells grown on MA ( $\mathrm{pH}$ 8.0) at $30{ }^{\circ} \mathrm{C}$.

Cell morphology was examined by using light microscopy (model DM3000; Leica). Gram staining and $\mathrm{KOH}$ lysis tests were carried out according to Smibert \& Krieg (1994) and Gregersen (1978), respectively. Flagella and endospores were examined according to the methods of Leifson and Schaeffer-Fulton, respectively (Smibert \& Krieg, 1994). Growth was tested at various temperatures $\left(4,5-55{ }^{\circ} \mathrm{C}\right.$, in increments of $\left.5{ }^{\circ} \mathrm{C}\right)$ and $\mathrm{pH}(5.0-11.0$, in increments of 0.5 units) on MA as well as in nutrient broth (NB) supplemented with $2.5 \%(\mathrm{w} / \mathrm{v}) \mathrm{NaCl}$. The buffer solutions described by Chen et al. (2007) were used for $\mathrm{pH}$ experiments. Growth in the absence of $\mathrm{NaCl}$ was investigated on nutrient agar (NA) and in NB prepared according to the formula of Atlas (1993) but without $\mathrm{NaCl}$. Tolerance to $\mathrm{NaCl}$ was tested on NA as well as in $\mathrm{NB}$ at different $\mathrm{NaCl}$ concentrations $[0.1$ and $0.5 \%(\mathrm{w} / \mathrm{v})$, and $1-30 \%(\mathrm{w} / \mathrm{v})$ in increments of $1 \%]$. Methyl red and Voges-Proskauer tests, and determination of $\mathrm{H}_{2} \mathrm{~S}$ production from L-cysteine, egg yolk reaction, hydrolysis of aesculin, indole production, nitrate and nitrite reduction, and arginine dihydrolase, lysine and ornithine decarboxylase, phenylalanine deaminase and urease activities were carried out as described by Smibert \& Krieg (1994). Hydrolysis of casein, cellulose, DNA, gelatin, starch, ONPG, and Tweens 20, 40, 60 and 80 was determined as described by Cowan \& Steel (1965). Growth under anaerobic conditions was determined on MA supplemented with $0.5 \%(\mathrm{w} / \mathrm{v})$ glucose and with or without $0.1 \%$ $(\mathrm{w} / \mathrm{v})$ nitrate by using the GasPak anaerobic system (BBL) according to the manufacturer's instructions. Determination of acid production from carbohydrates and utilization of carbon and nitrogen sources was performed as described by Ventosa et al. (1982). Motility, and catalase and oxidase activities were determined as described previously (Chen et al., 2007). Other enzymic activities were assayed by using API ZYM strips (bioMérieux) according to the manufacturer's instructions with $3 \%(\mathrm{w} / \mathrm{v}) \mathrm{NaCl}$. All physiological and biochemical tests were repeated three times.

Cells of strain JSM $081004^{\mathrm{T}}$ were Gram-stain-positive, endospore-forming, motile, slightly halophilic, facultatively anaerobic, straight rods, with optimum growth occurring in the presence of $2-4 \%(\mathrm{w} / \mathrm{v}) \mathrm{NaCl}$, at $\mathrm{pH} 8.0$ and at 25-30 ${ }^{\circ} \mathrm{C}$. Colonies were yellow-pigmented, flat, opaque with smooth, glistening surfaces and circular/slightly irregular margins, and $2-3 \mathrm{~mm}$ in diameter after incubation for 3-4 days at $30{ }^{\circ} \mathrm{C}$ on MA. Detailed phenotypic properties that differentiate strain JSM $081004^{\mathrm{T}}$ from related species of the genus Bacillus are summarized in Table 1 and also mentioned in the species description below.

Genomic DNA was isolated according to Hopwood et al. (1985) and the $\mathrm{G}+\mathrm{C}$ content was determined using the HPLC method (Mesbah et al., 1989). The 16S rRNA gene was amplified by PCR and sequenced as described by Cui et al. (2001). Pairwise sequence similarities were calculated using a global alignment algorithm, implemented at the EzTaxon server (Chun et al., 2007). Phylogenetic analysis was performed by using the software package MEGA version 4.1 (Tamura et al., 2007) after multiple alignment of sequence data by CLUSTAL x (Thompson et al., 1997). Distances were calculated using distance options according to Kimura's two-parameter model (Kimura, 1980) and clustering was performed by the neighbour-joining method (Saitou \& Nei, 1987). Maximum-likelihood (Felsenstein, 1981) and maximum-parsimony (Kluge \& Farris, 1969) trees were generated by using the tree-making algorithms contained in the PHYLIP package (Felsenstein, 2002). Bootstrap analysis was used to evaluate tree topology by means of 1000 resamplings (Felsenstein, 1985). After the DNA was purified to an absorbance ratio of $A_{260}$ versus $A_{280}$ higher than 1.8, DNA-DNA hybridization experiments were performed according to the optical renaturation method (De Ley et al., 1970; Huß et al., 1983; Jahnke, 1992) using a UV-1206 spectrophotometer (Shimadzu) equipped with a TB-85 thermo-bath. Every hybridization experiment was repeated five times and the highest and lowest values in each experiment were excluded. DNADNA relatedness values were expressed as the means of the remaining three values.

The DNA G + C content of strain JSM $081004^{\mathrm{T}}$ was $40.1 \mathrm{~mol} \%$. The almost-complete $16 \mathrm{~S}$ rRNA gene sequence (1467 bp) was determined. Phylogenetic analysis based on 16S rRNA gene sequences revealed that strain JSM $081004^{\mathrm{T}}$ should be assigned to the genus Bacillus and was related most closely to $B$. lehensis $\mathrm{MLB}^{\mathrm{T}}$ (16S rRNA gene sequence similarity of $97.8 \%$; Ghosh et al., 2007), B. oshimensis $\mathrm{K}_{11}^{\mathrm{T}}$ (97.8\%; Yumoto et al., 2005) and B. patagoniensis PAT $05^{\mathrm{T}}$ (97.3\%; Olivera et al., 2005); sequence similarities less than $95.5 \%$ were observed with other species of the genus Bacillus. The neighbour-joining phylogenetic tree further confirmed that strain JSM $081004^{\mathrm{T}}$ was closely related phylogenetically to members of the genus Bacillus and formed a robust lineage with the type strains of B. lehensis, B. oshimensis, B. patagoniensis and Bacillus clausii (95.3\% similarity; Nielsen et al., 1995) (Fig. 1). Topology was similar to those of the phylogenetic trees reconstructed by using maximum-likelihood and maximum-parsimony methods (Supplementary Fig. S1, available in IJSEM Online). Levels of DNA-DNA relatedness of strain JSM $081004^{\mathrm{T}}$ with B. lehensis DSM $19099^{\mathrm{T}}$, B. oshimensis DSM $18940^{\mathrm{T}}$ and B. patagoniensis DSM $16117^{\mathrm{T}}$ were $18.6 \%$ (SD of $1.8 \%$ ), $17.9 \%$ (SD of $1.5 \%$ ) and $16.4 \%$ (SD of $1.7 \%$ ), respectively, values that are well below the threshold value $(70 \%)$ recommended by Wayne et al. 
Table 1. Characteristics used to distinguish strain JSM $081004^{\top}$ from the type strains of phylogenetically related species of the genus Bacillus

Strains: 1 , B. xiaoxiensis sp. nov. JSM $081004^{\mathrm{T}} ; 2$, B. lehensis DSM $19099^{\mathrm{T}} ; 3$, B. oshimensis DSM $18940^{\mathrm{T}} ; 4$, B. patagoniensis DSM $16117^{\mathrm{T}}$. All strains are endospore-forming, Gram-stain-positive rods that can grow in the presence of $1-15 \%(\mathrm{w} / \mathrm{v}) \mathrm{NaCl}$, at $\mathrm{pH} 7.0-10.5$ and at $10-40{ }^{\circ} \mathrm{C}$. All strains are positive for catalase activity and hydrolysis of casein, gelatin, starch and Tween 20 . All strains are negative for: egg yolk reaction; indole and $\mathrm{H}_{2} \mathrm{~S}$ production; hydrolysis of cellulose and ONPG; nitrite reduction; methyl red and Voges-Proskauer tests; and arginine dihydrolase, phenylalanine deaminase, and lysine and ornithine decarboxylase activities. All data were obtained from this study unless indicated otherwise. + , Positive; - , negative.

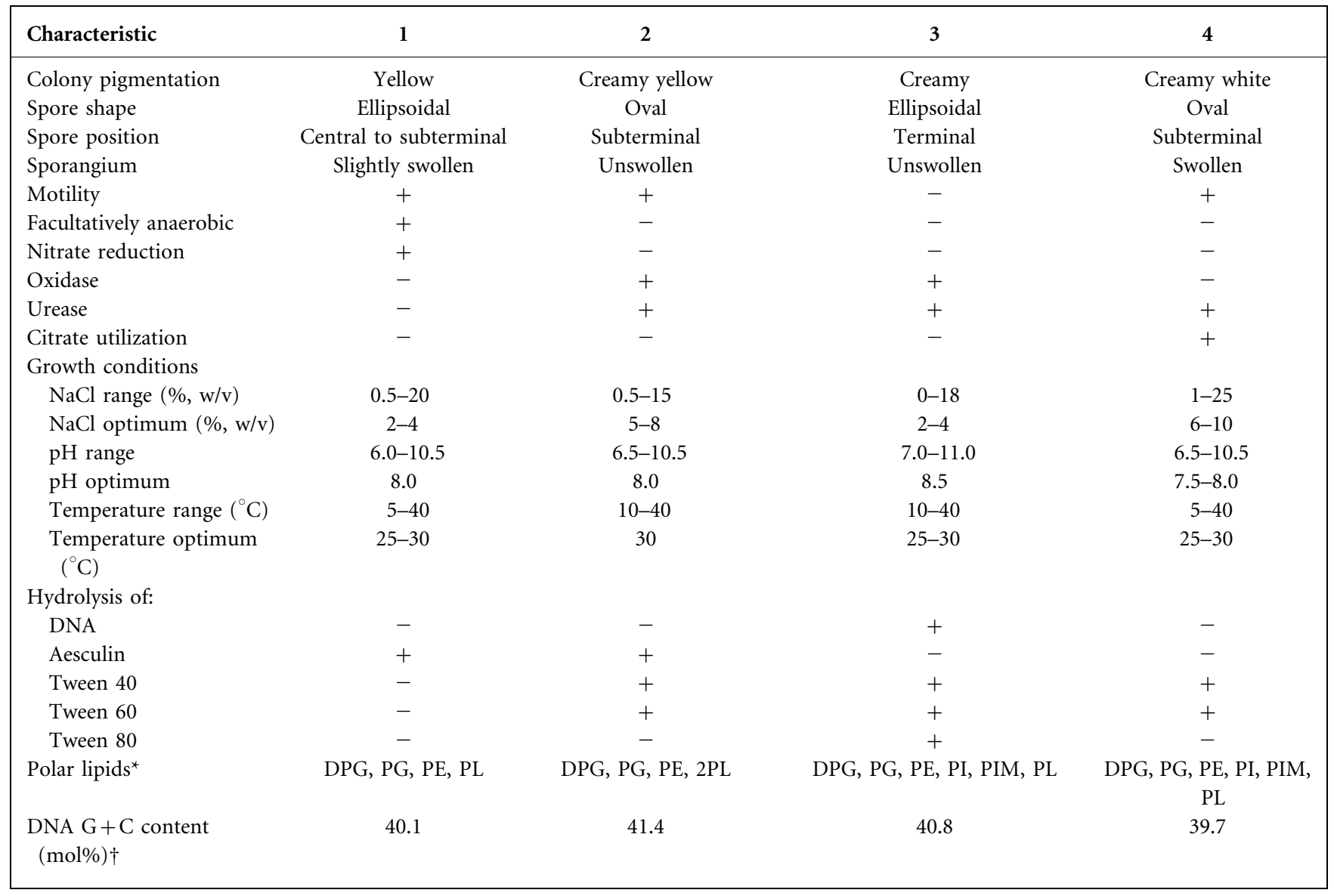

${ }^{\star}$ DPG, Diphosphatidylglycerol; PG, phosphatidylglycerol; PE, phosphatidylethanolamine; PI, phosphatidylinositol; PIM, phosphatidylinositol mannoside; PL, unidentified phospholipid.

$\dagger$ Data for the type strains of B. lehensis, B. oshimensis and B. patagoniensis were obtained from Ghosh et al. (2007), Yumoto et al. (2005) and Olivera et al. (2005), respectively.

(1987) for the definition of members of a species. Therefore, it would appear that, on the basis of phylogenetic and DNA-DNA hybridization data, strain JSM $081004^{\mathrm{T}}$ represents a novel species of the genus Bacillus according to accepted criteria (Wayne et al., 1987; Stackebrandt \& Goebel, 1994).

Amino acids of whole-cell hydrolysates were analysed by TLC as described by Hasegawa et al. (1983). Isoprenoid quinones were analysed by HPLC as described by Groth et al. (1996). Polar lipids were extracted according to the method of Minnikin et al. (1979) and identified by twodimensional TLC; total lipid material and specific functional groups were detected using Dittmer-Lester reagent (phosphate-containing lipids), ninhydrin (free amino groups), Dragendorff reagent (quaternary nitrogen) and anisaldehyde/sulfuric acid (glycolipids) (Dittmer \& Lester, 1964; Vaskovsky et al., 1975; Ryu \& MacCoss, 1979; Collins \& Jones, 1980). Fatty acids were determined according to Sasser (1990) using the Microbial Identification System (Microbial ID) with cells grown in marine broth 2216 (Difco) in flasks on a rotary shaker (with shaking at 200 r.p.m.) at $30{ }^{\circ} \mathrm{C}$ for 2 days.

Chemotaxonomic data for strain JSM $081004^{\mathrm{T}}$ were consistent with assignment of the strain to the genus Bacillus. The strain possessed a cell-wall type based on meso-diaminopimelic acid as the diagnostic diamino acid. 


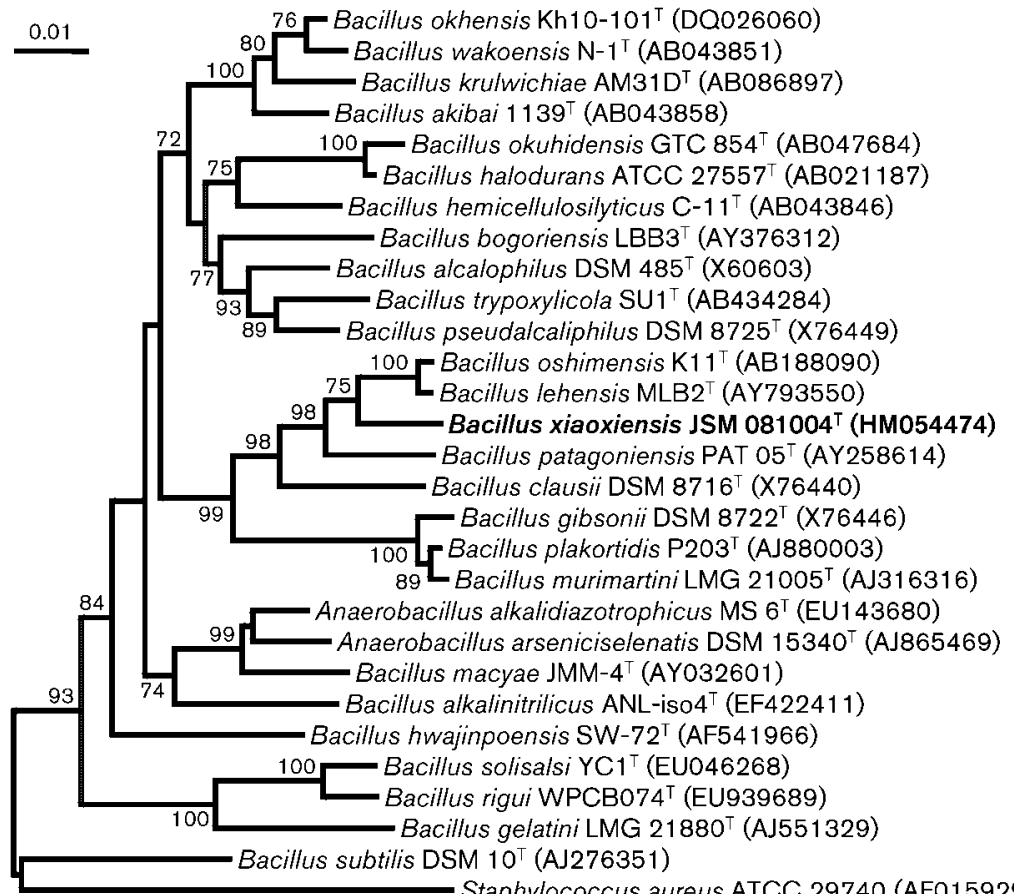

Fig. 1. Phylogenetic tree showing the position of strain JSM $081004^{\top}$ and related taxa based on 16S rRNA gene sequence analysis reconstructed by using the neighbour-joining method. Numbers at nodes are bootstrap percentages $(>70 \%)$ based on a neighbourjoining analysis of 1000 resampled datasets. Bar, 1 substitution per 100 nt.
Strain JSM $081004^{\mathrm{T}}$ contained MK-7 $(96.4 \%)$ as the predominant menaquinone, with MK-6 (1.1\%) and MK-8 $(2.5 \%)$ present in minor amounts. The polar lipids of this strain consisted of diphosphatidylglycerol, phosphatidylethanolamine, phosphatidylglycerol and one unknown phospholipid (Table 1). The fatty acid profile of strain JSM $081004^{\mathrm{T}}$ was similar to those of the type strains of the three phylogenetically related species of the genus Bacillus, although there were differences in the proportions of some components (Table 2). The fatty acid profile of strain JSM $081004^{\mathrm{T}}$ contained the major compounds iso- $\mathrm{C}_{15: 0}$ $(75.4 \%)$ and anteiso- $\mathrm{C}_{15: 0}(11.5 \%)$, which are characteristic of numerous members of the genus Bacillus (Kämpfer, 1994).

The results of the phylogenetic analysis and of morphological and chemotaxonomic investigations supported the affiliation of strain JSM $081004^{\mathrm{T}}$ to the genus Bacillus. However, the yellow pigmentation of strain JSM $081004^{\mathrm{T}}$, as well as the ability to grow under anaerobic conditions and reduce nitrate to nitrite, together with several other phenotypic characteristics and chemotaxonomic data, differentiated the isolate clearly from its phylogenetic relatives (Tables 1 and 2). In conclusion, phylogenetic analysis based on 16S rRNA gene sequences, DNA-DNA relatedness results, and phenotypic and chemotaxonomic data presented here support the proposal that strain JSM $081004^{\mathrm{T}}$ represents a novel species of the genus Bacillus, Bacillus xiaoxiensis sp. nov.

\section{Description of Bacillus xiaoxiensis sp. nov.}

Bacillus xiaoxiensis (xi.a.o.xi.en'sis. N.L. masc. adj. xiaoxiensis pertaining to Xiaoxi National Natural Reserve,
Table 2. Fatty acid compositions of strain JSM $081004^{\top}$ and related species of the genus Bacillus

Strains: 1 , B. xiaoxiensis sp. nov. JSM $081004^{\mathrm{T}} ; 2$, B. lehensis DSM $19099^{\mathrm{T}}$; 3, B. oshimensis DSM $18940^{\mathrm{T}}$; 4, B. patagoniensis DSM $16117^{\mathrm{T}}$. Data are percentages of the total fatty acid content. - , Not detected. All data were from this study.

\begin{tabular}{|lcccc|}
\hline Fatty acid & $\mathbf{1}$ & $\mathbf{2}$ & $\mathbf{3}$ & $\mathbf{4}$ \\
\hline Saturated & & & & \\
$\quad \mathrm{C}_{14: 0}$ & 0.5 & 1.2 & 0.8 & 0.4 \\
$\mathrm{C}_{16: 0}$ & 1.5 & 3.4 & 1.9 & 0.8 \\
$\mathrm{C}_{18: 0}$ & 0.4 & 1.3 & 0.3 & - \\
Unsaturated & & & & \\
$\quad \mathrm{C}_{16: 1} \omega 7 c$ alcohol & 0.8 & 0.6 & 0.3 & 3.7 \\
$\mathrm{C}_{16: 1} \omega 11 c$ & 0.2 & - & 0.2 & 0.6 \\
Branched & & & & \\
iso- $\mathrm{C}_{13: 0}$ & 0.4 & 0.3 & 0.3 & 0.2 \\
iso- $\mathrm{C}_{14: 0}$ & 3.7 & 6.7 & 6.6 & 7.9 \\
iso- $\mathrm{C}_{15: 0}$ & 74.5 & 63.9 & 63.9 & 50.7 \\
anteiso- $\mathrm{C}_{15: 0}$ & 11.5 & 13.3 & 16.8 & 24.6 \\
iso- $\mathrm{C}_{16: 0}$ & 1.7 & 3.4 & 2.8 & 3.5 \\
iso- $\mathrm{C}_{17: 0}$ & 2.5 & 3.9 & 3.8 & 2.8 \\
anteiso- $\mathrm{C}_{17: 0}$ & 0.9 & 1.4 & 1.4 & 2.4 \\
iso- $\mathrm{C}_{17: 1} \omega 10 c$ & - & - & - & 0.7 \\
iso- $\mathrm{C}_{18: 0}$ & 0.2 & - & - & - \\
$\mathrm{C}_{18: 1} \omega 9 c$ & 1.0 & 0.5 & 0.4 & 0.1 \\
Summed feature $4^{*}$ & - & - & - & 1.0 \\
& & & & \\
\hline
\end{tabular}

${ }^{\star}$ Summed features are groups of two or three fatty acids that cannot be separated by GLC with the MIDI system. Summed feature 4 comprises iso- $\mathrm{C}_{17: 1} \mathrm{I}$ and/or anteiso- $\mathrm{C}_{17: 1} \mathrm{~B}$. 
China, the source of the sample from which the type strain was isolated).

Cells are Gram-stain-positive, catalase-positive, oxidasenegative, slightly halophilic, facultatively anaerobic, straight rods, approximately $0.6-1.2 \mu \mathrm{m}$ wide and $3.0-5.0 \mu \mathrm{m}$ long, occurring singly, as pairs or as short chains, producing ellipsoidal endospores that lie in central to subterminal, slightly swollen sporangia. Motile by means of peritrichous flagella. Colonies are yellow-pigmented, flat and opaque, have smooth, glistening surfaces and circular/slightly irregular margins, and are $2-3 \mathrm{~mm}$ in diameter on MA. No diffusible pigments are produced. Growth occurs with $0.5-20 \%(\mathrm{w} / \mathrm{v}) \mathrm{NaCl}$ (optimum 2-4\%), at pH 6.0-10.5 (optimum $\mathrm{pH}$ 8.0) and at $5-40{ }^{\circ} \mathrm{C}$ (optimum $25-30{ }^{\circ} \mathrm{C}$ ). Nitrate is reduced to nitrite, but nitrite is not further reduced. Negative for egg yolk reaction, methyl red, VogesProskauer, $\mathrm{H}_{2} \mathrm{~S}$ and indole production tests. Aesculin, casein, gelatin, starch and Tween 20 are hydrolysed, but cellulose, DNA, ONPG, and Tweens 40, 60 and 80 are not. Acids are produced from amygdalin, D-glucose, glycerol, glycogen, maltose, D-mannitol, melibiose, raffinose, starch and sucrose, but not from $\mathrm{N}$-acetylglucosamine, adonitol, L-arabinose, cellobiose, dulcitol, D-fructose, D-galactose, myo-inositol, lactose, D-mannose, melezitose, L-rhamnose, D-ribose, D-salicin, D-sorbitol, trehalose or D-xylose. The following compounds are utilized as sole sources of carbon and energy or sole sources of carbon, nitrogen and energy: D-glucose, glycogen, D-mannose, D-xylose, amygdalin, glycerol, D-salicin, acetate and L-asparagine. The following are not utilized: L-arabinose, cellobiose, dextrin, D-fructose, D-galactose, lactose, maltose, melezitose, melibiose, raffinose, L-rhamnose, D-ribose, sucrose, trehalose, adonitol, D-arabitol, myo-inositol, D-mannitol, D-sorbitol, butyrate, citrate, gluconate, propionate, succinate, $\mathrm{N}$-acetylglucosamine, L-alanine, L-arginine, L-glutamic acid, glycine, L-histidine, hydroxy L-proline, L-isoleucine, L-leucine, L-methionine, L-phenylalanine, L-proline, L-serine and L-valine. Alkaline phosphatase, $\alpha$-chymotrypsin, esterase (C4), esterase lipase (C8), leucine arylamidase and naphthol-AS-BIphosphohydrolase are expressed constitutively; acid phosphatase, arginine dihydrolase, cystine arylamidase, $\alpha$ fucosidase, $\alpha$ - and $\beta$-galactosidase, $\alpha$ - and $\beta$-glucosidase, $N$-acetyl- $\beta$-glucosaminidase, $\beta$-glucuronidase, lipase (C14), lysine decarboxylase, $\alpha$-mannosidase, ornithine decarboxylase, phenylalanine deaminase, trypsin, urease and valine arylamidase activities are not observed. mesoDiaminopimelic acid is present in the cell-wall peptidoglycan as the diagnostic diamino acid. Possesses MK-7 as the predominant menaquinone, and diphosphatidylglycerol, phosphatidylethanolamine and phosphatidylglycerol as the major polar lipids. Major fatty acids are iso- $\mathrm{C}_{15: 0}$ and anteiso- $\mathrm{C}_{15: 0}$.

The type strain is JSM $081004^{\mathrm{T}}\left(=\right.$ CCTCC AA $208057^{\mathrm{T}}$ $\left.=\mathrm{DSM} 21943^{\mathrm{T}}\right)$, isolated from non-saline forest soil in Xiaoxi National Natural Reserve, China. The DNA G +C content of the type strain is $40.1 \mathrm{~mol} \%$ (HPLC method).

\section{Acknowledgements}

This work was supported by grants from the National Basic Research Program of China (2010CB833800), National Natural Science Foundation of China (NSFC) (30860013, 30970007), Key Laboratory of Ecotourism's Application Technology of Hunan Province (SL2010Z01) and International Cooperation Research Program of Yunnan Province (2009AC017). We are grateful to Mr Zhu-Xiang Liu and Mr Ke Huang for their excellent technical assistance.

\section{References}

Arahal, D. R. \& Ventosa, A. (2002). Moderately halophilic and halotolerant species of Bacillus and related genera. In Applications and Systematics of Bacillus and Relatives, pp. 83-99. Edited by R. C. W. Berkeley, M. Heyndrickx, N. Logan \& P. De Vos. Oxford: Blackwell.

Ash, C., Farrow, J. A. E., Wallbanks, S. \& Collins, M. D. (1991). Phylogenetic heterogeneity of the genus Bacillus as revealed by comparative analysis of small-subunit-ribosomal RNA sequences. Lett Appl Microbiol 13, 202-206.

Atlas, R. M. (1993). Handbook of Microbiological Media. Edited by L. C. Parks. Boca Raton, FL: CRC Press.

Chen, Y.-G., Cui, X.-L., Pukall, R., Li, H.-M., Yang, Y.-L., Xu, L.-H., Wen, M.-L., Peng, Q. \& Jiang, C.-L. (2007). Salinicoccus kunmingensis sp. nov., a moderately halophilic bacterium isolated from a salt mine in Yunnan, south-west China. Int J Syst Evol Microbiol 57, 2327-2332.

Chen, Y.-G., Zhang, Y.-Q., Xiao, H.-D., Liu, Z.-X., Yi, L.-B., Shi, J.-X., Zhi, X.-Y., Cui, X.-L. \& Li, W.-J. (2009a). Pontibacillus halophilus sp. nov., a moderately halophilic bacterium isolated from a sea urchin. Int J Syst Evol Microbiol 59, 1635-1639.

Chen, Y.-G., Zhang, Y.-Q., Wang, Y.-X., Liu, Z.-X., Klenk, H.-P., Xiao, H.-D., Tang, S.-K., Cui, X.-L. \& Li, W.-J. (2009b). Bacillus neizhouensis sp. nov., a halophilic marine bacterium isolated from a sea anemone. Int J Syst Evol Microbiol 59, 3035-3039.

Chen, Q., Liu, Z., Peng, Q., Huang, K., He, J., Zhang, L., Li, W. \& Chen, Y. (2010). [Diversity of halophilic and halotolerant bacteria isolated from non-saline soil collected from Xiaoxi National Natural Reserve, Hunan Province]. Wei Sheng Wu Xue Bao 50, 1452-1459 (in Chinese).

Chun, J., Lee, J.-H., Jung, Y., Kim, M., Kim, S., Kim, B. K. \& Lim, Y.-W. (2007). EzTaxon: a web-based tool for the identification of prokaryotes based on 16S ribosomal RNA gene sequences. Int J Syst Evol Microbiol 57, 2259-2261.

Collins, M. D. \& Jones, D. (1980). Lipids in the classification and identification of coryneform bacteria containing peptidoglycans based on 2,4-diaminobutyric acid. J Appl Bacteriol 48, 459-470.

Cowan, S. T. \& Steel, K. J. (1965). Manual for the Identification of Medical Bacteria. London: Cambridge University Press.

Cui, X.-L., Mao, P.-H., Zeng, M., Li, W.-J., Zhang, L.-P., Xu, L.-H. \& Jiang, C.-L. (2001). Streptimonospora salina gen. nov., sp. nov., a new member of the family Nocardiopsaceae. Int J Syst Evol Microbiol 51, 357-363.

De Ley, J., Cattoir, H. \& Reynaerts, A. (1970). The quantitative measurement of DNA hybridization from renaturation rates. Eur $J$ Biochem 12, 133-142.

Dittmer, J. C. \& Lester, R. L. (1964). A simple, specific spray for the detection of phospholipids on thin-layer chromatograms. J Lipid Res 15, 126-127.

Echigo, A., Hino, M., Fukushima, T., Mizuki, T., Kamekura, M. \& Usami, R. (2005). Endospores of halophilic bacteria of the family Bacillaceae isolated from non-saline Japanese soil may be transported by Kosa event (Asian dust storm). Saline Syst 1, 8.

Echigo, A., Fukushima, T., Mizuki, T., Kamekura, M. \& Usami, R. (2007). Halalkalibacillus halophilus gen. nov., sp. nov., a novel 
moderately halophilic and alkaliphilic bacterium isolated from a nonsaline soil sample in Japan. Int J Syst Evol Microbiol 57, 1081-1085.

Felsenstein, J. (1981). Evolutionary trees from DNA sequences: a maximum likelihood approach. J Mol Evol 17, 368-376.

Felsenstein, J. (1985). Confidence limits on phylogenies: an approach using the bootstrap. Evolution 39, 783-791.

Felsenstein, J. (2002). PHYLIP (phylogeny inference package), version 3.6a. Distributed by the author. Department of Genome Sciences, University of Washington, Seattle, USA.

Ghosh, A., Bhardwaj, M., Satyanarayana, T., Khurana, M., Mayilraj, S. \& Jain, R. K. (2007). Bacillus lehensis sp. nov., an alkalitolerant bacterium isolated from soil. Int J Syst Evol Microbiol 57, 238-242.

Gregersen, T. (1978). Rapid method for distinction of Gram-negative from Gram-positive bacteria. Eur J Appl Microbiol Biotechnol 5, 123-127.

Groth, I., Schumann, P., Weiss, N., Martin, K. \& Rainey, F. A. (1996). Agrococcus jenensis gen. nov., sp. nov., a new genus of actinomycetes with diaminobutyric acid in the cell wall. Int J Syst Bacteriol 46, 234-239.

Hasegawa, T., Takizawa, M. \& Tanida, S. (1983). A rapid analysis for chemical grouping of aerobic actinomycetes. J Gen Appl Microbiol 29, 319-322.

Hopwood, D. A., Bibb, M. J., Chater, K. F., Kieser, T., Bruton, C. J., Kieser, H. M., Lydiate, D. J., Smith, C. P., Ward, J. M. \& Schrempf, H. (editors) (1985). Genetic Manipulation of Streptomyces. A Laboratory Manual. Norwich: John Innes Foundation.

Horikoshi, K. (1999). Alkaliphiles: some applications of their products for biotechnology. Microbiol Mol Biol Rev 63, 735-750.

Huß, V. A. R., Festl, H. \& Schleifer, K. H. (1983). Studies on the spectrophotometric determination of DNA hybridization from renaturation rates. Syst Appl Microbiol 4, 184-192.

Jahnke, K. D. (1992). BASIC computer program for evaluation of spectroscopic DNA renaturation data from Gilford System 2600 spectrophotometer on a PC/XT/AT type personal computer. J Microbiol Methods 15, 61-73.

Kämpfer, P. (1994). Limits and possibilities of total fatty acid analysis for classification and identification of Bacillus species. Syst Appl Microbiol 17, 86-98.

Kimura, M. (1980). A simple method for estimating evolutionary rates of base substitutions through comparative studies of nucleotide sequences. J Mol Evol 16, 111-120.

Kluge, A. G. \& Farris, F. S. (1969). Quantitative phyletics and the evolution of anurans. Syst Zool 18, 1-32.

Krulwich, T. A., Hicks, D. B., Swartz, T. H. \& Ito, M. (2007). Bioenergetic adaptations that support alkaliphily. In Physiology and Biochemistry of Extremophiles, pp. 311-329. Edited by C. Gerday \& N. Glansdorff. Washington, DC: American Society for Microbiology.

Lim, J.-M., Jeon, C. O. \& Kim, C.-J. (2006a). Bacillus taeanensis sp. nov., a halophilic Gram-positive bacterium from a solar saltern in Korea. Int J Syst Evol Microbiol 56, 2903-2908.

Lim, J.-M., Jeon, C. O., Lee, S.-M., Lee, J. C., Xu, L. H., Jiang, C. L. \& Kim, C. J. (2006b). Bacillus salarius sp. nov., a halophilic, sporeforming bacterium isolated from a salt lake in China. Int J Syst Evol Microbiol 56, 373-377.

Margesin, R. \& Schinner, F. (2001). Potential of halotolerant and halophilic microorganisms for biotechnology. Extremophiles 5, 73-83.

Mesbah, M., Premachandran, U. \& Whitman, W. B. (1989). Precise measurement of the $\mathrm{G}+\mathrm{C}$ content of deoxyribonucleic acid by highperformance liquid chromatography. Int J Syst Bacteriol 39, 159-167.

Minnikin, D. E., Collins, M. D. \& Goodfellow, M. (1979). Fatty acid and polar lipid composition in the classification of Cellulomonas, Oerskovia and related taxa. J Appl Microbiol 47, 87-95.
Nielsen, P., Rainey, F. A., Outtrup, H., Priest, F. G. \& Fritze, D. (1994). Comparative $16 \mathrm{~S}$ rDNA sequence analysis of some alkaliphilic bacilli and the establishment of a sixth rRNA group within the genus Bacillus. FEMS Microbiol Lett 117, 61-66.

Nielsen, P., Fritze, D. \& Priest, F. G. (1995). Phenetic diversity of alkaliphilic Bacillus strains: proposal for nine new species. Microbiology 141, 1745-1761.

Nogi, Y., Takami, H. \& Horikoshi, K. (2005). Characterization of alkaliphilic Bacillus strains used in industry: proposal of five novel species. Int J Syst Evol Microbiol 55, 2309-2315.

Olivera, N., Siñeriz, F. \& Breccia, J. D. (2005). Bacillus patagoniensis sp. nov., a novel alkalitolerant bacterium from the rhizosphere of Atriplex lampa in Patagonia, Argentina. Int J Syst Evol Microbiol 55, 443-447.

Romano, I., Lama, L., Nicolaus, B., Gambacorta, A. \& Giordano, A. (2005). Bacillus saliphilus sp. nov., isolated from a mineral pool in Campania, Italy. Int J Syst Evol Microbiol 55, 159-163.

Ryu, E. K. \& MacCoss, M. (1979). Modification of the Dittmer-Lester reagent for the detection of phospholipid derivatives on thin-layer chromatograms. J Lipid Res 20, 561-563.

Saitou, N. \& Nei, M. (1987). The neighbor-joining method: a new method for reconstructing phylogenetic trees. Mol Biol Evol 4, 406-425.

Sasser, M. (1990). Identification of bacteria by gas chromatography of cellular fatty acids, MIDI Technical Note 101. Newark, DE: MIDI Inc.

Smibert, R. M. \& Krieg, N. R. (1994). Phenotypic characterization. In Methods for General and Molecular Bacteriology, pp. 607-654. Edited by P. Gerhardt, R. G. E. Murray, W. A. Wood \& N. R. Krieg. Washington, DC: American Society for Microbiology.

Stackebrandt, E. \& Goebel, B. M. (1994). Taxonomic note: a place for DNA-DNA reassociation and $16 \mathrm{~S}$ rRNA sequence analysis in the present species definition in bacteriology. Int J Syst Bacteriol 44, 846-849.

Tamura, K., Dudley, J., Nei, M. \& Kumar, S. (2007). MEGA4: molecular evolutionary genetic analysis (MEGA) software version 4.0. Mol Biol Evol 24, 1596-1599.

Thompson, J. D., Gibson, T. J., Plewniak, F., Jeanmougin, F. \& Higgins, D. G. (1997). The CLUSTAL_X windows interface: flexible strategies for multiple sequence alignment aided by quality analysis tools. Nucleic Acids Res 25, 4876-4882.

Usami, R., Echigo, A., Fukushima, T., Mizuki, T., Yoshida, Y. \& Kamekura, M. (2007). Alkalibacillus silvisoli sp. nov., an alkaliphilic moderate halophile isolated from non-saline forest soil in Japan. Int $J$ Syst Evol Microbiol 57, 770-774.

Vaskovsky, V. E., Kostetsky, E. Y. \& Vasendin, I. M. (1975). A universal reagent for phospholipid analysis. J Chromatogr A 114, 129-141.

Ventosa, A., Quesada, E., Rodriguez-Valera, F., Ruiz-Berraquero, F. \& Ramos-Cormenzana, A. (1982). Numerical taxonomy of moderately halophilic Gram-negative rods. J Gen Microbiol 128, 1959-1968.

Ventosa, A., Nieto, J. J. \& Oren, A. (1998). Biology of moderately halophilic aerobic bacteria. Microbiol Mol Biol Rev 62, 504-544.

Wayne, L. G., Brenner, D. J., Colwell, R. R., Grimont, P. A. D., Kandler, O., Krichevsky, M. I., Moore, L. H., Moore, W. E. C., Murray, R. G. E. \& other authors (1987). International Committee on Systematic Bacteriology. Report of the ad hoc committee on reconciliation of approaches to bacterial systematics. Int J Syst Bacteriol 37, 463-464.

Yumoto, I. (2007). Environmental and taxonomic biodiversities of Gram-positive alkaliphiles. In Physiology and Biochemistry of Extremophiles, pp. 295-310. Edited by C. Gerday \& N. Glansdorff. Washington, DC: American Society for Microbiology.

Yumoto, I., Hirota, K., Goto, T., Nodasaka, Y. \& Nakajima, K. (2005). Bacillus oshimensis sp. nov., a moderately halophilic, non-motile alkaliphile. Int J Syst Evol Microbiol 55, 907-911. 